\title{
A Concept of Society-Earth-Centric Narratives
}

\author{
MARTIN BOHLE* \\ Directorate General Research and Innovation, European Commission \\ martin.bohle@ec.europa.eu \\ ANNA SIBILLA* \\ EASME \\ anna.sibilla@ec.europa.eu \\ ROBERT CASALS I GRAELLS* \\ Council of the European Union \\ robert.casalsgraells@consilium.europa.eu
}

\begin{abstract}
This essay presents a concept of narratives as powerful means for people to associate themselves with anthropogenic global change. The starting point of our reflection is that people's awareness is related to their story-telling practices to communicate insights and to induce or inspire behaviour. By analysing traditional and modern settings of "Earthcentric" narratives and their respective societal context, one can sketch the necessary features of society-Earth-centric narratives. These features seem suitable to raise public awareness, in particular of urban people, of the interaction of human activities and the Earth system, and of anthropogenic global change.
\end{abstract}

\section{INTRODUCTION}

$\mathrm{H}$ uman-driven change of natural environment has been a concern since the onset of the industrial revolution [Fressoz, 2012; Lewis and Maslin, 2015; Waters et al., 2016].

Full understanding of Earth system dynamics requires insight into people-people interactions and people-Earth interactions. Sound humanEarth system interactions need reliable science and engineering expertise as well as the valueloaded considerations of the ethical, social and cultural implications of human activities [Press, 2008; Biermann, 2012; Wilson, 2014; Ellis, 2015; Ellis et al., 2016; Veland and Lynch, 2016]. As anthropologists attest, humans are storytellers [Pagel, 2012; Wilson, 2012].

Throughout the history of humankind, narratives were developed to share insights among people and to guide their behaviour. This essay sketches how the weaving of several concerns into common threads should lead to compelling narratives that can raise public awareness of the intersections of human activities with the Earth system; that is, of anthropogenic global change.

\section{EARTH-CENTRIC NARRATIVES: PAST AND PRESENT}

Traditional communities refer to the marvellous to ascribe meaning to natural phenomena and to maintain social cohesion. By the same means, these communities control the exploitation of the environment on which they depend. As an example arising from the western tradition, some rural alpine cultures in the Aosta Valley in the Italian Alps have maintained these approaches into contemporary times [Sibilla, 2012]. Their particular narration is about how the rugged mountains around the valley protects its greenest and most fertile grounds from human exploitation.

These types of traditional narratives were Earth-centric to inspire a behaviour that might sustain stable and lasting human-Earth system interactions. The behaviour was justified with 
faith-based reasoning referring to the supernatural, which were common and shared views in the respective communities [Durand, 1960; Whitehouse and McCauley, 2005; Botero et al., 2014]. Although based mainly on faith and beliefs, the traditional thinking was functional because it had encoded practical experiences into a solid frame of reference values. When this traditional basis is disrupted by explanations that use insights into natural processes and technologies, the traditional balance in the community between "Earth-centric" and "society-centric" goals can be altered. This alteration can disrupt the equilibrium of people's relationships with the Earth system. To encourage an Earth-centric behaviour, modern societies that dwell on science and technology, industrialisation, and global urbanisation will need to incorporate other narratives, as the traditional societies did. With a greater awareness of Earth processes and the health of ecosystems, public concerns about pollution, hazard mitigation, demographics, and use of resources become familiar, in particular for urban populations [Fressoz, 2012]. Contemporary narratives of human-Earth system interactions have to use natural science, humanities and history, anthropology, philosophy, and politics to strike a knowledge-based balance between "Earthcentric" and "society-centric" contents [Kleinhans et al., 2010; Philipps, 2012].

\section{ILLUSTRATING MODERN GEOSCIENCE NARRATIVES}

Landscapes, history, or art can furnish ample opportunities for narratives about geoscience matters and societal concerns. The following is an example to illustrate what we mean by "opportunities" [Bohle, 2015]. Crater Lake is situated in a caldera in south-central Oregon (USA). This unique lake was a sacred site for the native Klamath tribe. Their legends tell of battling gods, of sky and underworld, and establish Crater Lake as a profoundly spiritual place. The deep lake was formed around 7,700 years ago by the collapse of a volcanic caldera [Zdanowicz et al., 1999]. It has neither surfacewater inflow nor outlet, and is known for the clarity and dark blue colour of its water, which reflects the sky and backscatters blue light. Evidently, bringing the legend and modern sci- ence in context with the beauty and uniqueness of the site offers an attractive story. Modern society-Earth-centric narratives draw on scientific knowledge from humanities and natural sciences. It is postulated that additional features are needed to make the narrative operational that is, to render it society-Earth-centric, namely: it must hold relevance for mundane matters; it must address value creation; and it must reflect urban lifestyle.

- Relevance for mundane matters. Daily weather and, over longer time intervals, climate can exert significant impact on humans' lives. Weather reports for specific professional audiences have been produced since the mid-19 century. Regular weather forecast became feasible since the early 1950s [Bauer et al., 2015]. Today, modern media combine in a single narrative the weather forecast, information on meteorological phenomena, and impacts on economic activities. These meteorologist's narratives about mundane matters provide a benchmark.

- Addressing value creation. The application of geosciences allows modern societies to function. Craftsman, technicians, architects, and engineers use geoscience when they create artificial environments, extract minerals, determine the stability of foundations, or in myriad other activities in which they create engineered works in a geological context. Beyond offering economic value, geoscience provides cultural value - it provides reliable knowledge about the lifesupporting functions of the Earth's systems [Hazen, 2012]. Narratives about these cases of applied geosciences help us understand the development of human-geosphere interactions and the perception of history [Latour, 2013].

- Reflecting urban lifestyle. The Gilgamesh poem and the story of Uruk (a town built 5000 years ago in Mesopotamia) are fascinating cultural artefacts through which ancient city-dwellers recorded their obvious connections with the geosphere [George, 1999]. In the modern urban environment, the experiential connections of people with the geosphere are constrained. Experiential connections of urban people with the geo- 
sphere are biased towards events that disrupt the proper functioning of the engineered structures that form their dwellings and support their lifestyles. When modern city dwellers are isolated from nature through engineered environments, their lives are dominated by social experiences. An urban lifestyle resonates in dense people-people interactions. Any Earth-centric narrative must link to these familiar societycentric narratives in order to be fully understood.

Modern society-Earth-centric narratives are told in the context of anthropogenic global change, although the effect of people's activity on Earth has been noticeable for several thousand years [Foley et al., 2013]. Today, human impact on Earth's environment goes beyond regional industrial pollution, urbanisation of rural areas, or replacing pristine wilderness by rural landscapes [Ellis et al., 2013], regardless of whether these impacts are endogenous or even understood by society.

Non-scientists perceive contemporary anthropogenic global change in their own ways, and public perception of the widespread effects of economic activity on the Earth system is generally limited. Moreover, it is not yet fully evident how these interactions depend on culture and the individual or shared values of people [Bohle, 2016]. Still, to handle these interactions efficiently and effectively, society will have to be aware of them. As most people live in towns, narratives for urban dwellers are particularly needed and must be focused on familiar societal perceptions and values in order to be useful. Effective narratives should engage a wide cross section of society, including those who have expert knowledge, are practitioners, represent traditional knowledge, or share views of lobbies or political representatives [Hulme, 2011].

\section{A FRAMEWORK FOR SOCIETY-EARTH- CENTRIC NARRATIVES}

We can draw upon what we know to suggest what sorts of society-Earth-centric narratives are needed. First, acknowledge that people shape their environment in response to their needs as these are perceived through the filter of their world-views and preferences. In that context, people use narratives to develop abstract mental concepts, compare them with observations, assess their cultural and social background, or influence others through making value statements.

Second, acknowledge that people's narratives about the intersections of their activities with the Earth system have evolved throughout history. Learn from that history, that narratives can have richer features than is provided by science alone, and should include a focus on people and social interactions. To achieve awareness of the public, narratives have to be both Earth-centric and society-centric [Gluckman, 2014].

Third, acknowledge that everybody needs to understand the interactions of human economic activity and the Earth system, and therefore narratives have to stay within the average person's ordinary value-loaded frame of reference [Lidström et al., 2015].

Society-Earth-centric narratives benefit from geoscience expertise that is relevant for both economy and value setting, and is interwoven with arts, linguistic and cultural histories.

\section{SUMMARY}

The historical and political discourse about the path of human development during recent centuries [Malanima, 2010] shows how people entered the Anthropocene: "Ces histories nous invitent à reprendre politiquement la main sur des institutions, des élites sociales, des systèmes symboliques et matériels puissantes qui nous ont fait basculer dans l'Anthropocène" [Bonneuil and Fressoz, 2013; page 27: "These stories invite us to take control of political institutions, social elites, powerful symbolic and material systems that have tipped us into the Anthropocene."]. Global anthropogenic change is now part of the public perception of 'the state of the globe.' Many people in western culture perceive this scenario as a threat to their lifestyle and well-being [Ehrlich et al., 2012; Biermann et al., 2012; Walton and Shaw, 2015].

Facing anthropogenic global change requires a public debate that is anchored in experiences [Moore, 2016] and supported by society-Earth- 
centric narratives. Rich narratives can be spun on a broad range of perspectives: (i) beauty or particularity of ordinary or unusual phenomena, (ii) evaluating hazards for or from mundane environments, (iii) relevance for everyday matters, creating value and (iv) relating to people-people interactions. Only when geoscience matters are woven into engaging narratives can people connect to them within their framework(s) of values and culture.

\section{REFERENCES}

Bauer P., Thorpe A. and Brunet G. (2015). The Quiet Revolution of Numerical Weather Prediction. Nature, 525: 47-55, doi:10.1038/ nature14956.

Biermann F., Abbott K., Andresen S., Bäckstrand K., Bernstein S., Betsill M. M., Bulkeley H., Cashore B., Clapp J., Folke C., Gupta A., Gupta J., Haas P. M., Jordan A., Kanie N., Kulvánková-Oravská T., Lebel L., Liverman D., Meadowcroft J., Mitchel R. B., Newell P., Oberthür S., Olsson L., Pattberg P., Sánchez-Rodríguez R., Schroeder H., Underdal A., Camargo Vieira S., Vogel C., Young O. R., Brock A. and Zondervan R. (2012). Navigating the Anthropocene: Improving Earth System Governance, Science, 335: 1306-1307.

Bohle M. (2015). Simple geoethics: an essay on daily Earth science. Geological Society London Special Publications, 419(1): 5-12, DOI:10.1144/SP419.3.

Bohle M. (2016). Handling of HumanGeosphere Intersections. Geosciences 6(1), doi:10.3390/geosciences6010003. http:/ / www.mdpi.com/2076-3263/6/1/3.

Bonneuil Ch. and Fressoz J. B. (2013). L'événement Anthropocène - La terre, l'histoire et nous, Paris: Le Seuil 1-271 pp.

Botero C., Gardner B., Kirby K. R., Bulbulia J., Gavin, M. C. and Gray R. D. (2014). The ecology of religious beliefs, PNAS 11147: 16784-16789, doi: 10.1073/pnas.1408701111.

Descola Ph. (2011). L'écologie des autres. L'anthropologie et la question de la nature. Paris: Éditions Quae. 1-112 pp.

Durand G. (1960). Les Structures anthropologiques de l'imaginaire. Paris: Press Universitaire de France, 1-95 pp.
Ehrlich P. R., Kareiva P. M. and Daily G. C. (2012). Securing natural capital and expanding equity to rescale civilisation. Nature 486: 68-73.

Ellis E. C. (2015). Ecology in an Anthropogenic Biosphere. Ecological Monographs 85(3): 287-331. doi:10.1890/14-2274.1.

Ellis E. C., Kaplan J. O., Fuller D. Q., Vavrus S., Klein Goldewijk K. and Verburg P. H. (2013). Used Planet: A Global History. Proceedings of the National Academy of Sciences 110(20): 7978-7985. doi:10.1073/pnas.1217241110.

Ellis E. C., J. Richerson P. J., Mesoudi A., Svenning J. Ch., Odling-Smee J. and Burnside W. R. (2016). Evolving the Human Niche. Proceedings of the National Academy of Sciences 113(31): E4436-E4436. doi:10.1073/pnas.1609425113.

Foley J.A., Ramankutty N., Brauman K. A., Cassidy E. S., Gerber J. S., Johnston M., Mueller N. D., O'Connell Ch., Ray D. K., West P. C., Balzer Ch., Bennett E. M., Carpenter St. R., Hill J., Monfreda Ch., Polasky S., Rockström J., Sheehan J., Siebert S., Tilman D. and Zaks D. P. M. (2013). Solutions for a cultivated planet, Nature 478:.337-342, doi:10.1038/ nature10452.

Fressoz J. B. (2012). L'Apocalypse joyeuse - Une histoire $\mathrm{du}$ risque technologique. Paris: Le Seuil, 1-312 pp.

George A. (1999). The Epic of Gilgamesh. London: Pinguin Books, 1- 228 pp.

Gluckman P. (2014). The art of science advice to government, Nature 507: 163-165.

Hazen R. M. (2012). The Story of Earth. London: Viking Pinguin, 1-306 pp.

Hulme M. (2011). Meet the Humanities. Nature Climate Change 1(4): 177-179. doi:10.1038/nclimate1150.

http: / / www.nature.com/ doifinder/10.103 8/nclimate1150.

Kleinhans M. G., Buskes Ch. J. J. and de Regt H. W. (2010). Philosophy of Earth Science. In: Fritz Allhoff [editor) Philosophies of the Sciences, 213-236. Oxford: Wiley-Blackwell. doi:10.1002/9781444315578.ch9.

Latour B. (2013). Facing Gaia: Six Lectures on the Political Theology of Nature. Gifford Lectures on Natural Religion, Edinburgh, 
18-28 February 2013: 1-144 pp. http: / / www.brunolatour.fr/sites / default / files / downloads / G IFFORD-SIX-LECTURES_1.pdf.

Lewis S. L. and Maslin M. A. (2015). Defining the Anthropocene. Nature 519:171-180, doi: 10.1038 / nature14258.

Lidström S., West S., Katzschner T., PérezRamos M. I. and Twidle H. (2015). Invasive Narratives and the Inverse of Slow Violence: Alien Species in Science and Society. Environmental Humanities 7: 1-40.

Malanima P. (2010). Europäische Wirtschaftsgeschichte 10.-19. Jahrhundert. Vienna: Böhlau Verlag, 1-493 pp.

Moore A. (2016). Anthropocene Anthropology: Reconceptualizing Contemporary Global Change. Journal of the Royal Anthropological Institute 22(1): 27-46. doi:10.1111/14679655.12332.

Pagel M. (2012). Wired for Culture. Origins of the Human Social Mind, New York: W.W. Norton \& Company, 1-423 pp.

Phillips J. (2012). Storytelling in Earth sciences: Eight basic plots. Earth-Science Reviews 115: 153-162. doi: 10.1016/j.earscirev.2012.09.005.

Press F. (2008). Earth Science and Society. Nature 451: 301-303. doi:10.1038/ nature06595.

Sibilla P. (2012). Approdi e Percorsi, saggi di antrolologia alpina. Firenze: Leo Olschki Editore pp. $51-68$.

Veland S. and Lynch A. H. (2016). Scaling the Anthropocene: How the Stories We Tell Matter. Geoforum 72: 1-5. doi:10.1016/j.geoforum.2016.03.006.

Walton T. and Shaw W. S. (2015). Living with the Anthropocene Blues. Geoforum 60:1-3. doi:10.1016/j.geoforum.2014.12.014.

Waters C. N., Zalasiewicz J., Summerhayes C., Barnosky A. D., Poirier C., Galuszka A., Cearreta C., Edgeworth M., Ellis E. C., Ellis M., Jeandel C., Leinfelder R., McNeill J. R., Richter D. deB., Steffen W., Syvitski J., Vidas D., Wagreich M., Williams M., Zhisheng A., Grinevald J., Odada E., Oreskes N. and Wolfe A. P. (2016). The Anthropocene Is Functionally and Stratigraphically Distinct from the Holocene. Science 351: aad2622-aad2622. doi:10.1126/science.aad2622.
Whitehouse H. and McCauley R. (2005). Mind and Religion - Psychological and Cognitive Foundation of Religiosity. Oxford: Altamira Press, 1-248 pp.

Wilson E. O. (2012). The social conquest of Earth. New York: W.W. Norton \& Company, 1- 331 pp.

Wilson E. O. (2014). The Meaning of Human Existence. New York: W.W. Norton \& Company, 1-207 pp.

Zdanowicz Ch., Zielinski G. A. and Germani M. S. (1999). Mount Mazama eruption; calendrical age verified and atmospheric impact assessed. Geology 277: 621-624.

\footnotetext{
* Disclaimer: All views expressed herein are entirely of the author, do not reflect the position of the European Institutions or bodies and do not, in any way, engage any of them.

Acknowledgement: The authors are grateful to their employers for the consent to work on these matters outside their profession al duties. The authors declare no conflict of interest. This paper is the extended version of the author's contribution to the 35 International Geological Congress, 2016 Cape Town. The affiliation of third author was at the Research Executive Agency (REA) when the work was performed. Finally, the authors like to thank the anonymous reviewer for their help.
} 